\section{Crohn's Disease and its Consequences}

SIR,-Your leading article on Crohn's Disease and its Consequences (11 April p. 65) says "Psychological factors are generally held not to be aetiologically important" and cites to support such a "generally held" view but one reference, and that to an article which has been much criticised on account of its methodology.

Dare I suggest that such selectivity if practised by psychiatrists would quite properly call down the wrath of medical science? To redress the balance I draw your attention to a few recent articles giving the opposite view. ${ }^{1-4}$-I am, etc.,

Ipswich, Suffolk.

J. W. Paulley.

REFERENCES

Whybrow, P. C., Kane F. J., and Lipton M. A. Psychosomatic Medicine, 1968, 30, 209.

Reinhart, J. B., and Succop, R. A., fournal of the American Academy of Child Psychiatry, 1968 7, 252.

Ford, C. V., Glober, G. A., and CastelnuovoTedexo, P., fournal of the

1 Goldberg, D., Gut, 1970, in press.

\section{Haemoglobinopathies and Anaesthesia}

SIR,-YYour Today's Drugs article on this subject (11 April, p. 98) infers that a conclusive result on the sickling test can be obtained in 30 minutes. This is usually true for homozygous sickle cell disease and for $\mathrm{Hb}$ SC disease. It is certainly not true for the sickle cell trait. It is my practice never to give a report on a test for sickling that is negative until it has been incubated overnight. Even then a few cases with a negative sickling test have been found to have $\mathrm{Hb} \mathrm{S}$ present on electrophoresis. A further sickling test on these patients has always been positive.

It cannot be overstressed that until haemoglobin electrophoresis has been carried out the sickle cell trait cannot be excluded. It follows, therefore, that any member of a race in which $\mathrm{Hb} S$ is known to occur must be assumed to have the sickle cell trait until it has been excluded by electrophoresis.-I am, etc.,

\section{R. Davis.}

Belgrave Hospital for Children,

London S.W.9.
Lond

\section{Haemophilus aphrophilus Endocarditis}

SIR,-Drs. R. M. Pine and H. S. Ballard (9 May, p. 344) while giving an account of an interesting clinical case, are inaccurate in naming the organism isolated as belonging to the sDecies $H$. aphrophilus.

By definition a member of the genus Haemophilus requires either $\mathrm{X}$ or $\mathrm{V}$ factor, or both. ${ }^{1}$ Some snecies, such as $H$. aphrophilus, in addition require incuba tion in air with its $\mathrm{CO}_{2}$ content increased to 5 to $10 \% .^{2}$ Furthermore, members of the genus Haemophilus do not produce gas when they form acid from carbohydrates. ${ }^{1}$

Testing for $\mathrm{X}$ factor requirements has its difficulties, for most conventional laboratory media may contain traces of $\mathrm{X}$ factor suf- ficient to allow growth of less exacting strains. Thus, such strains may appear not to require either $\mathrm{X}$ or $\mathrm{V}$ factor unless strict criteria are applied. ${ }^{3}$ Furthermore, $H$. aphrophilus strains may produce mutants capable of manufacturing small amounts of $\mathrm{X}$ factor, and thus, if mutants are inadvertently selected for subculturing, will appear to grow in the absence of $\mathrm{X}$ and $\mathrm{V}$ factors.

Drs. Pine and Ballard have not mentioned $\mathrm{X}$ dependence of their strains on first isolation with subsequent loss of that characteristic, already described by Khairat ${ }^{2}$ in his original observation. On the available evidence it seems, therefore, that the causative organism isolated on seven occasions was not $H$. aphrophilus, and probably not a member of the genus Haemophilus.

The purpose of this letter is to contribute to the removal of the confusion that has plagued classification of members of the genus Haemophilus since the misleading classification in the papers of King and Tatum $^{5}$ and Page and King ${ }^{6}$ which are quoted by Drs. Pine and Ballard.-I am, etc.,

\section{K. Zinnemann,}

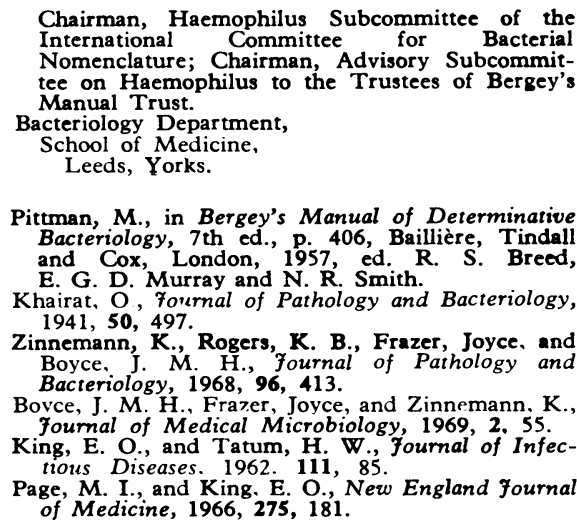

\section{Nifuratel for Trichomonal Vaginitis}

SIR,-We are able to confirm the recent report of the failure of nifuratel (Magmilor) in the treatment of trichomoniasis ( 9 May, p. 335). The drug is not to be compared in efficacy with metronidazole (Flagyl). It is well established that all topical preparations including metronidazole, if given locally are ultimately ineffective in curing trichomonal infection in the majority of patients. Only a systemic agent (such as metronidazole) is capable of eradicating the disease from the deeper epithelial layers of the vagina and surrounding glands.

We therefore conducted a trial to assess the relative efficiencv of vaginal against oral preparations of nifuratel. When nifuratel was used by us as a surface agent alone (as pessary) a cure rate of $62 \%$ was obtained. Interestingly, this cure rate is identical with that obtained by Drs. Evans and Catteral using nifuratel in a combination of tablets and pessaries. When we used nifuratel in tablet form bu mouth alone we obtained a cure rate of only $10 \% .^{2}$

The conclusion to be drawn is that nifuratel pessaries are certainly no more effective than anv other vaginal pessary in giving relief in trichnmonas vaginitis, and when given by mouth there is probably little or no systemic action. Thus nifuratel is unlikely to produce a permanent cure.-We are, etc.,

A. Grimble.

Guy's Hospital,
London S.E.1.

D. J. WRIGHT.

London S.E.1.
1 Durel, P., Roiron, V., Siboulet, A., and Borel,
L. J., British fournal of Venereal Diseases, 1960,
44, 331. Grimble, A., and Wright,
Trials fournal, in press.

\section{Cardiac Catheterization}

SIR,-We read with interest the Preliminary Communication from the cardiovascular unit of the Royal Postgraduate Medical School (28 March, p. 795).

We were, however, rather concerned about the extensive research procedures carried out on such ill patients, for whom there can be no immediate benefit.

We have talked to many patients who have undergone routine cardiac catheterization as a very necessary preliminary to cardiac surgery, and almost without exception they found this a frightening and often uncomfortable investigation. We also note that in this series "... none had received other drugs for at least six hours." Does this exclude premedication?

We feel that these research measures are not justified in this situation where peace of mind is all important.

We hope these observations will not seem too presumptuous, coming from two medical students, but feel strongly that enthusiasm for research should not outweigh the benefit to the individual patient.-We are, etc.,

\section{S. A. Copeland. N. H. BRoOKS.} St. Bartholomew's Hospital,

St. Bartholomew's
London E.C.1.

***We showed this letter to the authors of the preliminary communication, and their reply is printed below.-ED., B.M.7.

SIR,-Thank you for the opportunity of replying to the letter from $\mathrm{Mr}$. S. A. Copeland and Mr. N. H. Brooks. We entirely agree with the view that research involving patients should only be undertaken with the strictest attention to the interests of the individual and to the benefits that he may obtain. They are, however, labouring under a misapprehension when they compare routine cardiac catheterization in preparation for cardiac surgery with the techniaues used in our study. Routine preoperative catheterization involves the use of larger bore catheters inserted after preliminary skin incisions in a specially equipped catheter laboratory. The procedure, essential in the investigation of comolex cardiac defects, is usuallv performed in a darkened room using $x$-ray screening and it commonly involves the injection of contrast material, with associated unpleasant side-effects. In addition the patient may be placed in uncomfortable positions during angiocardiography and he may be temporarily disturbed by the noise of the film cassette changer. For these reasons, preparatory sedation is usually advisable.

In contrast, our studies were performed at the patients' bedside in the coronary care 